REFLEKSI EDUKATIKA : Jurnal Ilmiah Kependidikan

Volume 11 Nomor 1 Desember 2020

ISSN: 2087-9385 (print) dan 2528-696X (online) http://jurnal.umk.ac.id/index.php/RE

\title{
TIPE-TIPE POLA ASUH DALAM PENDIDIKAN KELUARGA
}

\author{
Rekno Handayani ${ }^{1}$, Imaniar Purbasari ${ }^{2}$, Deka Setiawan ${ }^{3}$ \\ ${ }^{1,2,3}$ Universitas Muria Kudus, Indonesia \\ Email: handayanirekno@.gmail.com
}

\begin{tabular}{|c|}
\hline Info Artikel \\
\hline $\begin{array}{l}\text { Sejarah Artikel: } \\
\text { Diserahkan } 6 \text { Desember } 2019 \\
\text { Direvisi } 10 \text { Agustus } 2020 \\
\text { Disetujui } 15 \text { Oktober } 2020\end{array}$ \\
\hline $\begin{array}{l}\text { Keywords: } \\
\text { parenting type, } \\
\text { primary education, } \\
\text { elementary school student }\end{array}$ \\
\hline
\end{tabular}

\begin{abstract}
This study aims to analyze the type of parenting in the family education of SD 1 Gulang students, Mejobo District, Kudus Regency.

This research is a qualitative descriptive study conducted in Gulang Village, Mejobo District, Kudus Regency. The research subjects were grade 4 students of SD 1 Gulang. The data collection techniques used include direct observation, interviews, research documentation, and note taking. Interviews were conducted with parents of students who implemented parenting, students, and teachers who were the main informants. In analyzing the data, the Milles Huberman model was used, namely the analysis was carried out including data collection, data reduction, data presentation and conclusion drawing.

The results showed that $S D 1$ Gulang students received family education from parents who applied various types of parenting styles. The following shows several types of parenting that are found (1) democratic patterns, democratic parenting is a form of parenting that is cooperative for children, but there are certain limitations, this pattern is able to provide maximum education in the family so that children have good character and social attitudes. (2) neglect, this form of parenting has a tendency for parents not to be involved at all in the child's life, (3) authoritarian, the family provides strict supervision to the child so that the parents are quite dominant in the child's life and (4) permissive, the parents In providing assistance, only providing needs without providing good family education to children. Of the four types of parenting found, it is known that democratic patterns are parenting styles that have a positive role for children. The three other parenting styles do not have a positive role. As a result, students become passive and cannot socialize well, so that family education is important for a child's life, especially SD 1 Gulang.
\end{abstract}

\begin{abstract}
Abstrak
Penelitian ini bertujuan untuk menganalisis tipe pola asuh dalam pendidikan keluarga siswa SD 1 Gulang Kecamatan Mejobo Kabupaten Kudus.

Penelitian ini merupakan penelitian deskriptif kualitatif yang dilaksanakan di Desa Gulang Kecamatan Mejobo Kabupaten Kudus. Subyek penelitian yaitu siswa kelas 4 SD 1 Gulang. Teknik pengumpulan data yang digunakan meliputi observasi langsung, wawancara, dokumentasi penelitian, dan pencatatan. Wawancara dilaksanakan dengan orang tua siswa yang menerapkan pengasuhan, siswa, dan guru yang ketiganya merupakan informan utama. Dalam menganalisis data digunakan model Milles Huberman yakni analisis dilakukan meliputi koleksi data, reduksi data, penyajian data dan penarikan kesimpulan.

Hasil penelitian menunjukan bahwa siswa SD 1 Gulang mendapatkan pendidikan keluarga dari para orang tua yang menerapkan berbagai tipe pola asuh. Berikut disajikan beberapa tipe pola asuh yang ditemukan (1) pola demokratis, bentuk pola asuh demokratis merupakan bentuk pengasuhan yang bersifat kooperatif kepada anak namun terdapat batasan tertentu, pola ini mampu memberikan pendidikan dalam keluarga secara maksimal sehingga anak memiliki budi pekerti dan sikap sosial yang baik. (2) penelantaran, bentuk pola asuh ini memiliki kecenderungan orang tua tidak terlibat sama sekali pada kehidupan anak, (3) otoriter, keluarga sangat memberikan pengawasan yang ketat kepada anak sehingga orang tua cukup mendominasi pada kehidupan anak dan (4) permisif, orang tua dalam memberikan pendampingan hanya memberikan kebutuhan saja tanpa memberikan pendidikan keluarga yang baik kepada anak. Dari empat tipe pola asuh yang ditemukan diketahui bahwa pola demokratis merupak pola asuh yang memiliki peranan positif kepada anak. Adapun tiga pola asuh lainnya tidak memiliki peranan yang positif. Akibatnya siswa menjadi pasif dan tidak dapat bersosial dengan baik, sehingga pendidikan keluarga menjadi penting keberadaanya bagi kehidupan seorang anak khususnya SD 1 Gulang.
\end{abstract}

(C) 2020 Universitas Muria Kudus 
Rekno Handayani, Imaniar Purbasari, Deka Setiawan

TIPE POLA ASUH DALAM PENDIDIKAN KELUARGA

REFLEKSI EDUKATIKA : Jurnal Ilmiah Kependidikan, Volume 11, Nomor 1, Desember 2020, hlm. 16-23

\section{PENDAHULUAN}

Keluarga yakni salah satu komponen penting dalam masyarakat. Bagi seorang anak keluarga merupakan pendidikan pertama yang ia dapatkan. Munib (2012: 72) menyatakan bahwa keluarga memiliki peran utama dan pertama dalam pendidikan. Keluarga mempunyai kedudukan utama dalam memberikan support terhadap seorang anak. Hal tersebut didukung pendapat dari Semiawan (2008: 63) yang menyebutkan bahwa keluarga ialah tempat pendidikan yang memiliki pengaruh kuat terhadap masa perkembangan anak. Keluarga yang dimaksud yakni orang tua yang memiliki peran dalam mendampingi anak atau disebut dengan pola atau gaya asuh.

Pola asuh memiliki kedudukan yang cukup penting dalam proses sosial di dalam sebuah keluarga dan memiliki pengaruh yang cukup pada kehidupan anak. Hal tersebut sejalan dengan pendapat Yeni (2017: 8) menyebutkan bahwa pola asuh adalah sebuah faktor yang cukup penting untuk menghambat atau mengembangkan sebuah kreativitas anak. Berdasarkan pendapat tersebut maka dapat diartikan bahwa pola asuh ialah proses dimana orang tua akan memberikan pendampingan dalam berbagai aspek dalam kehidupan seorang anak baik dari kebutuhan anak, kesenangan anak dan yang paling penting adalah pendidikan anak.

Keluarga yang saling menghargai dan terbuka akan memberikan pengaruh positif bagi anggotanya dalam hal ini anak. Anak akan mampu bersikap produktif, fleksibel, percaya diri, inisiatif, serta terbuka. Sesuai penjelasan tersebut maka dapat dimaknai bahwa pengasuhan yang baik dapat memberi pendidikan keluarga yang positif pula pada kehidupan anak.

Shocib (2010: 2017) menyebutkan bahwa pola asuh adalah orang tua yang mampu memberikan sebuah kewibawaan yang dapat dilihat oleh seorang anak, yang mampu memberikan dorongan, bimbingan, bantuan sebagai seorang anak yang berkarakter sehingga keadaanya diapresiasi oleh anak. Orang tua yang memberikan tipe atau bentuk pengasuhan tentunya memiliki caranya masing-masing karena hal demikian dipengaruhi oleh aspek dalam diri orang tua maupun lingkungan masyarakat. Terdapat orang tua yang lebih suka menggunakan cara keras terhadap anak tentunya orang tua memiliki alasan tersendiri menggunkan tipe tersebut. Namun terdapat orang tua juga yang menggunakan cara yang lebih berpihak kepada anak dan tentunya orang tua pasti memiliki alasan tersendiri.

Baumrind dalam (Santrock, 2020: 257) menyebut ada empat jenis atau bentuk pola asuh yakni pola asuh penelantaran, demokratis, otoriter, dan permisif. Beberapa tipe atau bentuk pola asuh tersebut pastinya memiliki kecenderungan perbedaan yang menonjol bahkan memiliki sifat pola pengasuhan yang berbanding terbalik seperti bentuk pola asuh otoriter yang dimana anak harus sepenuhnya mematuhi apa yang diinginkan orang tua terhadap anak, yang hal tersebut sangat berbeda dengan tipe pola pengasuhan demokratis yang dimana orang tua dengan anak lebih dapat bekerja sama dalam berkehidupan sehari-hari. Kemudian tipe pola asuh permisif yang orang tua tidak terlalu mempedulikan kehidupan seorang anak sehingga kontrol orang tua kurang maksimal, tipe tersebut memiliki sedikit kesamaan dengn tipe atau bentuk pola asuh penelantaran sebuah kebiasaan dimana orang tua tidak mau terlibat pada kehidupan anaknya bahkan anak cenderung dibiarkan sesuai apa yang diinginkan anak. Berbagai penjelasan tipe tersebut tentunya mampu memberikan output yang berbeda-beda dalam diri anak terutama pendidikan keluarga atau pendidikan primer untuk anak usia Sekolah Dasar.

Orang tua tentunya memiliki caranya tersendiri dalam pemberian dukungannya bagi seorang anak. Latar belakang keluarga diyakini menjadi penentu bagaimana orang tua memberikan pengasuhan bagi anak. Adanya pernyataan tersebut dibuktikan dengan temuan penelitian dari Keshavarz (2009) bahwa perilaku dan keterlibatan orang tua memainkan peran penting dalam pengembangan kompetensi sosial dan kognitif pada anak-anak. Perilaku mengasuh anak dan pengaruhnya bervariasi tergantung pada budaya yang berbeda.

Keadaan tersebut berarti bahwa cara anggota keluarga berinteraksi satu sama lain dipengaruhi oleh budaya masyarakat. Hal demikian diperkuat oleh temuan Winarti (2019) yakni latar belakang pendidikan anggota keluarga memiliki peran atau yang melatar belakangi pola asuh yang diterapkan. Penelitian tersebut memberikan penekanan bahwa terdapat hal yang berpengaruh dalam pemberian pola asuh yang diberikan kepada anak. Kemudian penelitian selanjutnya terkait dengan makna dari 
Rekno Handayani, Imaniar Purbasari, Deka Setiawan

TIPE POLA ASUH DALAM PENDIDIKAN KELUARGA

REFLEKSI EDUKATIKA : Jurnal Ilmiah Kependidikan, Volume 11, Nomor 1, Desember 2020, hlm. 16-23

pendidikan keluarga sendiri ialah oleh Anisah (2011) pendidikan keluarga sebagai salah satu bentuk pendidikan pertama bagi anak merupakan media yang tepat bagi setiap orang tua untuk mendidik, membimbing, dan mengasuh anakanaknya. Pendidikan keluarga atau pendidikan primer merupakan pendidikan yang pertama didapat seseorang sejak lahir yang bertujuan membentuk sikap dan kepribadian pada diri anak hingga ia mampu bersosialisasi dengan lingkungan masyarakat.

Begitu pentingnya keluarga mampu memberikan pendidikan yang baik terhadap anak tentu anak akan memiliki sikap sosial yang baik. Samsunuwiyati (2012) menyebut hubungan keluarga atau pengasuh ialah awal bagi dasar pembentukan perkembangan sosial dan emosional seorang anak. Pendidikan keluarga dapat memberi peran yang signifikan terhadap perkembangan anak maka pendidikan keluarga memiliki peran yang sangat penting untuk membentuk karakter seorang anak atau siswa usia sekolah dasar. Sesuai penjelasan yang telah disajikan, tujuan dari penelitian ini ialah mengkaji pendidikan keluarga yang diberikan orang tua berdasarkan tipe pola asuh kepada anak atau siswa sekolah dasar.

\section{METODE PENELITIAN}

Penelitian ini merupakan penelitian deskriptif kualitatif yang dilaksanakan di Kecamatan Mejobo Kabupaten Kudus dengan lokasi penelitian di Desa Gulang. Subjek penelitian yakni siswa kelas 4 SD 1 Gulang. Teknik dan instrumen pengumpulan data yang digunakan meliputi observasi langsung, wawancara, dokumentasi penelitian, dan pencatatan.

Sumber data penelitian ini diperoleh dari hasil pengamatan lapangan, dokumentasi, dan wawancara dengan informan. Adapun pelaksanaan wawancara dilaksanakan dengan orang tua siswa yang menerapkan pengasuhan, siswa dan guru yang ketiganya merupakan informan utama. Menggunakan jenis wawancara mendalam, dalam melaksanakan penelitian peneliti dapat menggali informasi sebanyakbanyaknya sesuai situasi dan kondisi di lapangan. Kemudian dalam menganalisis data peneliti menggunakan model Milles Huberman yakni analisis dilakukan meliputi koleksi data, resuksi data, penyajian data dan penarikan kesimpulan.
Tahap koleksi data didapatkan peneliti dari pengamatan dan pelaksanaan wawancara. Reduksi data dilakukan untuk mengklasifikasi data dari temuan penelitian. Adapun penyajian data dilakukan setelah tahap koleksi dan reduksi serta disajikan dalam bentuk narasi dekriptif. Terakhir tahapan penarikan kesimpulan setelah semua data terangkum dan disajikan dengan baik sehingga temuan pada penelitian ini dapat bersifat mutakhir serta bersifat objektif.

\section{HASIL DAN PEMBAHASAN}

Pendidikan dilaksanakan pada masyarakat, sekolah, dan keluarga, sehingga salah satu tanggung jawab tercapainya tujuan pendidikan umum terletak pada sebuah keluarga (Shocib, 2010). Sejalan dengan pendapat tersebut maka keluarga begitu memiliki peran yang sangat penting bagi pertumbuhan anak khususnya siswa sekolah dasar. Siswa sekolah dasar merupakan siswa yang memiliki karaktristik unik sehingga pendidikan dalam keluarga menjadi salah satu penentu keberhasilan generasi yang nantinya akan melanjutkan suatu sejarah kemana bangsa ini akan di bawa. Salah satu tujuan pendidikan dalam keluarga memberikan nilai moral, budaya, sikap hidup berbangsa dan bernegara kepada anggota keluarganya yang bersangkutan. Tentu orang tua disini yang memiliki peran penuh dalam mengendalikan anak.

Keluarga menjadi penentu output atau hasil dari baik buruknya sikap kepribadian serta karakteristik anak usia sekolah dasar. Didukung temuan penelitian Hosokawa (2019) yakni sebagian besar perkembangan anak di Jepang selama masa prasekolah atau sekolah dasar (5-6 tahun) dipengaruhi oleh gaya pengasuhan dari orang tua. Hal tersebut sejalan dengan pendapat (Euis, 2004: 18) yang menyebut bahwa pola asuh memiliki arti sebuah interaksi erat, yang bertujuan untuk mengarahkan anak untuk memiliki kecakapan dalam kehidupan seharihari.

\section{Tipe Pola Asuh Orang Tua Siswa SD 1 Gulang}

a. Pola Demokratis

Bentuk pola demokratis ialah pola asuh orang tua yang mampu bekerja sama serta bersifat kooperatif, dalam memberikan pendampingan di kehidupan sehari-hari. Hal tersebut berkaitan dengan pendapat Shapiro 
Rekno Handayani, Imaniar Purbasari, Deka Setiawan

TIPE POLA ASUH DALAM PENDIDIKAN KELUARGA

REFLEKSI EDUKATIKA : Jurnal Ilmiah Kependidikan, Volume 11, Nomor 1, Desember 2020, hlm. 16-23

(1999: 28) yakni orang tua demokratis lebih mengutamakan serta menghargai dorongan dan pujian, serta kemandirian bagi anak. Sedangkan (Shocib, 2010) menyebut bahwa keluarga yang menerapkan pengasuhan demokratis biasa terdapat pada keluarga seimbang.

Mengacu pada pendapat tersebut bahwa pengasuhan demokratis memiliki ciri khusus yakni orang tua akan memberikan kepercayaan berupa kebebasan anaknya dalam berkrativitas. Pola ini menunjukan sosialisasi di dalam keluarga mampu terjalin dengan baik. Tidak sedikit keluarga yang memiliki permasalahan karena kurangnya hubungan antar individu sehingga hal demikian menunjukan pentingnya keharmonisan dalam sebuah keluarga.

Temuan penelitian menunjukkan bahwa dalam memberikan pendampingan terhadap anak, orang tua siswa SD 1 Gulang menerapkan pola atau gaya asuh demokratis. Bentuk pola asuh tersebut terbukti mampu memberikan peran positif terhadap siswa SD 1 Gulang, ditunjukan salah satunya dengan prestasi di dalam maupun luar kelas oleh beberapa informan ZA, NA, dan $\mathrm{KB}$. Orang tua ZA, NA, dan KB menjelaskan bahwa pendidikan keluarga menjadi sangat penting untuk kehidupan anak kedepan. Orang tua dalam memberikan pengasuhan kerap memberikan nasihat-nasihat kepada siswa atau anak berupa budi pekerti.

Nasihat dan motivasi kerap diberikan kepada siswa agar tetap giat belajar sehingga anak memiliki kemampuan mengikuti pembelajaran di kelas dengan baik. Latar belakang pendidikan yang baik dan perekonomian keluarga yang stabil peran keluarga disini menjadi berfungsi dengan baik. Orang tua tipe demokratis ini dalam memberikan pendampingan berupa pendidikan primer kepada anak menerapkan kebiasaan-kebiasaan positif kepada anak, adapun kebiasaan sebagai berikut, a) kebiasaan beribadah dengan baik, b) belajar secara teratur, c) porsi bermain yang cukup, d) Kebiasaan bersosial dengan baik, e) berakktifitas dirumah secara teratur, f) disiplin di rumah.

Penerapan kebisasaan-kebiasaan tersebut mampu memberikan pendidikan keluarga yang dapat dikatakan berhasil, karena dengan kebiasaan yang disiplin diterapkan secara tidak langsung dapat membentuk kepribadian anak. Hal itu dibuktikan dengan aktifitas siswa yang baik di sekolah. Tidak hanya menyuruh dan memberi tahu, orang tua juga mengaku terlibat secara langsung pada aktifitas yang dibiasaakan kepada anak seperti menemani belajar, menemani beribadah, mengaji, serta kegiatan lainnya. Adapun temuan tersebut dikuatkan oleh Samsunuwiyati (2012: 165) yakni orang tua mampu memberikan contoh, semangat teladan, serta dorongan bagi seorang anak melalui bentuk penampingan yang demokratis. Dipertegas lagi dengan temuan oleh Widhiasih (2017) bahwa anak yang diasuh dengan cara yang harmonis atau demokratis mampu meningkatkan hasil belajar IPS pada kategori sangat baik. Dari penjelasan tersebut dapat ditarik benang merah bahwa tipe pola asuh demokratis dapat sebagai teladan bagi orang tua dalam melaksanakan pendidikan primer yang maksimal bagi siswa SD 1 Gulang.

\section{b. Pola Permisif}

Pola asuh permisif merupakan bentuk pola asuh dengan kecenderungan orang tua untuk tidak terlalu peduli pada hidup anak. Pola seperti ini biasa ditemukan pada keluarga yang memiliki kesibukan tinggi. Orang tua hanya memberikan perhatian anak berupa kebutuhan berupa materi. Orang tua pada ciri permisif memiliki kecenderungan kurang memiliki peran edukasi terhadap seorang anak. Menurut Baumrind dalam Samsunuwiyati (2012) keterlibatan orang tua pada hidup anak terjadi pada pengasuhan permisif serta berakibat pengendalian yang tidak baik atau buruk.

Temuan kedua menunjukan tipe pola asuh permisif, yang memiliki ciri orang tua tidak terlalu memberikan perhatian kepada anak. Temuan ini atas dasar proses wawancara dengan Ibu TS yakni salah satu orang tua siswa SD 1 Gulang yang menerapkan pola asuh permisif. Kemudian informan yang mendapatkan pola permisif yakni MRF anak dari Ibu TS memiliki kecenderungan tertinggal di kelas. Orang tua tidak terlalu memotivasi anak, selain hal tersebut keluarga juga membiarkan anak bermain sesuai kesenangan anak dengan alasan orang tua terlalu sibuk bekerja. Adanya kebebasan tersebut maka akan menjadikan dampak yang tidak baik bagi anak karena bagaimanapun seorang anak harus mendapatkan perhatian lahir batin dari orang tua.

Selain itu latar belakang pendidikan tingkat sekolah dasar dan jenis pekerjaan yang tidak bisa ditinggalkan menjadi alasan oraang tua kurang maksimal dalam memberikan peran pendidikan primer kepada anak. akibat dari 
Rekno Handayani, Imaniar Purbasari, Deka Setiawan

TIPE POLA ASUH DALAM PENDIDIKAN KELUARGA

REFLEKSI EDUKATIKA : Jurnal Ilmiah Kependidikan, Volume 11, Nomor 1, Desember 2020, hlm. 16-23

kurangnya pendidikan dalam keluarga yang diterima oleh anak. Anak atau siswa menjadi pasif dalam beraktifitas di lingkungan sekolah. Informan orang tua Ibu TI menjelaskan dirinya hanya memberikan kebutuhan bersifat material kepada anak atau siswa dengan alasan ketika pagi sudah harus bekerja sehingga anak atau siswa tidak meemperoleh perhatian dari keluarganya. Sejalan dengan temuan penelitian oleh Jannah (2012) keluarga yang menerapkan pola permisif berdampak pada perilaku moral yang tidak baik pada anak. kaitanya dengan hal tersebut disimpulkan bahwa tipe pola permisif dalam memberikan pendidikan dalam keluarga atau pendidikan primer menghasilkan output yang kurang baik khususnya Siswa SD 1 Gulang.

\section{c. Pola otoriter}

Pola asuh otoriter merupakan corak pendampingan yang menerapkan sebuah aturan yang sangat ketat terhadap anak. Hampir tidak terdapat toleransi dengan apa yang sudah ditentukan oleh keluargan. Ciri dari pola ini orang tua memegang penuh kendali pada kehidupan anak. Menurut Baumrind dalam Samsunuwiyati (2012) model asuh otoriter memiliki ciri yang jelas yakni kontrol atau pengawasan yang ketat terhadap sikap tingkah laku anaknya. Pola otoriter tentunya memiliki peranan yang positif maupun negatif bagi anak. Peran negatifnya yakni anak tidak memiliki kebebasan untuk mengembangkan apa yang ada di dalam pikirannnya sehingga anak memiliki sikap yang pendiam serta cenderung individualisme.

Kemudian hasil temuan berikutnya tidak ditemukan pola otoriter pada siswa SD 1 Gulang. Tipe ini memiliki ciri-ciri hampir tidak ada waktu bermain untuk anak. Namun pada hasil temuan penelitian jarang orang tua menggunakan tipe atau bentuk pengasuhan otoriter. Hal tersebut dipengaruhi oleh banyak hal yakni perkembangan budaya masyarakat yang lebih modern sehingga orang tua lebih bisa berdemokrasi terhadap anak.

Kemudian pengetahuan masyarakat yang lebih modern sehingga tidak sepenuhnya anak itu diberikan pengasuhan dengan cara yang keras. Tipe pola asuh ini hampir tidak memberikan anak untuk berkreasi atau berkreatif sehingga anak akan menjadi pasif dan pendiam. Keluarga yang menerapkan tipe pola ini biasnnya dilatarbelakangi oleh profesi seperti prajurit TNI dan POLRI. Pada temuan penelitian disimpulkan bahwa pendidikan keluarga tipe pola asuh otoriter lebih mementingkan keteraturan dalam kehidupan sehari-hari namun mengesampingkan psikis dari anak sehingga output yang didapatkan anak menjadi pribadi yang idelais yang tidak mampu beradaptasi di lingkungan masyarakat.

\section{d. Pola penelantaran}

Tipe Pola penelantaran yakni gaya asuh orang tua memiliki kecenderungan menelantarkan anak bahkan sama sekali tidak terlibat apapun dalam diri anak. Pola ini biasa terjadi pada keluarga yang memiliki permasalahan baik internal maupun eksternal sehingga dampaknya secara langsung tidak langsung dirasakan oleh anak. Pola ini sangat memberikan dampak negatif bagi anak, anak memiliki kecenderungan untuk hidup seenaknya sendiri tanpa kontrol dari orang tua hingga ia mampu menjadi momok dalam sebuah masyarakat yang rukun.

Pada temuan penelitian yang telah dilaksanakan tidak ditemukan orang tua yang menggunakan bentuk pola asuh penelantaran. Tipe ini memungkinkan bahwa seorang anak akan mengalami permasalahan psikis maupun fisik. Pada tipe ini biasa terjadi pada keluarga yang mengalami sengketa internal atau broken home sehingga anak mendapati dampak secara langsung dari permasalaham dalam keluarga. Melihat esensi dari tipe pola asuh penelantaran memungkinkan tidak terjadi pendidikan primer yang baik dalam kehidupan berkeluarga karena keluarga itu sendiri mengalami permasalahan hingga terjadi ketidakpastian pendidikan dalam keluarga. Hal tersebut berbanding terbalik dengan teori yang mengatakan kelurga merupakan pendidikan yang menentukan keberhasilan dari seorang anak. Dari uraian tersebut dikatakan bahwa hampir tidak ada pendidikan primer dalam keluarga yang menerapkan tipe pengasuhan penelantaran.

Tipe-tipe pola asuh yang telah dijabarkan tentunya memiliki nilai positif dan negatif tergantung bagaimana orang tua menyikapi seorang anak. berdasar hasil penelitian dapat di tarik benang merah bahwa penerapan pendidikan keluarga akan menjadi lebih maksimal atau lebih bisa dirasakan oleh seorang siswa yakni siswa SD 1 Gulang adalah pengunaan tipe pola asuh demokratis. Terjadi hubungan yang seimbang antara orang tua dengan anak. Komunikasi 
Rekno Handayani, Imaniar Purbasari, Deka Setiawan

TIPE POLA ASUH DALAM PENDIDIKAN KELUARGA

REFLEKSI EDUKATIKA : Jurnal Ilmiah Kependidikan, Volume 11, Nomor 1, Desember 2020, hlm. 16-23

terjalin dengan baik sehingga anak memiliki sikap yang terbuka sesuai dengan yang dijelaskan oleh informan yakni Ibu PI. Orang tua lebih menekankan kebiasaan yang megandung nilai religius sebagai hal yang penting untuk siswa SD 1 Gulang. Penerapan kebiasaan seperti beribadah dan mengaji menjadi salah satunya. Tidak hanya itu orang tua kerap mendampingi anak dalam aktivitas belajar dirumah sehingga seorang anak dapat merasakan hangatnya kasih sayang yang diberikan orang tua.

Menurut (Shocib, 2010) keluarga harmonis antara orang tua dengan anak, anak dengan ayah, ayah dengan ibu, ibu dengan anak selalu dijumpai pada keluarga yang seimbang atau keluarga sehat. Untuk tipe pola lain yang diantaranya seperti tipe pola asuh permisif, otoriter, dan penelantaran hasil penelitian tidak menunjukan terdapat pendidikan di dalam keluarga yang menekankan nilai-nilai religius maupun nilai kedisiplinan yang diterapkan oleh orang tua kepada siswa SD 1 Gulang sehingga dalam tipe ini tidak terjadi output pendidikan keluarga sesuai yang diharapkan.

Hasil riset yang dilakukan senada dengan penelitian Rohmaniah, Khamdun, dan Widianto (2020) yang menyebut bahwa The results obtained explained that the democratic parenting style becomes the most efficient parenting style than other types of parenting in order to support learning motivation. A total of 21 respondents used democratic parenting style as a pattern of parenting and influenced elementary school students' learning motivation. Positive parenting would encourage high motivation in learning for student.

\section{Peran Pendidikan Keluarga Siswa SD 1 Gulang}

Pendidikan keluarga merupakan pendidikan yang diterma seorang anak sejak lahir. Anak mulai diperkenalkan oleh orang tua tentang budi pekerti yang baik guna untuk memperoleh karakter yang mampu menjadikan diri sebagai pribadi yang utuh. Hal tersebut sejalan yang dikemukakan oleh (Mansur, 2005) tumbuh kembang nilai positif seorang anak dapat dicapai melalui pendidikan keluarga. Hal tersebut telah dibuktikan temuan penelitian sebelumnya oleh Suharsono (2009) yang menunjukan bahwa terdapat kaitan pola asuh terhadap sosialisasi pada anak usia dini atau prasekolah di TK Pertiwi Purwokerto. Tentunya keluarga memiliki peran cukup penting bagi proses kembangnya seorang anak atau siswa usia SD.

Hasil penelitian yang dilaksanakan di Desa Gulang dengan subjek penelitian siswa kelas 4 SD 1 Gulang serta orang tua sebagai informan utama menunjukan bahwa pendidikan dalam keluarga memiliki peranan yang penting bagi seorang anak atau siswa SD 1 Gulang. Peranan tersebut ditunjukan oleh orang tua dalam memberikan pendidikan bagi anak melalui pembelajaran budi pekerti yang diterakan di dalam rumah. Penanaman kebiasaan yang mencerminkan nilai positif mampu memberi efek yang positif pula.

Adapun temuan tersebut didukung oleh Ismaya (2012) dan Zubaedi (2012). Ismaya (2012) menyebut bahwa Sedulur Sikep society runs their education through family - parents to their children. Sedulur Sikep Dukuh Kaliyoso never does and even wants to give their children education to formal institution, non-formal, and informal. They set out the education value. Education value appears in the form of an ethic that forbids to: drengki; srei; panasten; kemeren; dahwen; nyiyo marang sepodo; lan bejok reyot iku sedulure, waton menungso tur gelem di ndaku sedulur. It exists in a taboo tenet: bedok; colong; jumput; pethil; nemu wae ora keno. Beside that it also exist a basic tenet in self principled: kudu weruh tek-e dhewe; lugu; rukun; lan mligi. Sementara itu Zubaedi (2012) menyebut bahwa peran penting dalam keluarga adalah memerikan pendidikan karakter serta proses perkembangan seorang anak perlu adanya dukungan dari semua pihak, baik masyarakat, sekolah, dan keluarga. Sesuai dengan hal tersebut maka tentu pendidikan keluarga menjadi awal penentu bagaimana anak akan terbentuk kepribadiannya.

Bagi seorang siswa, pendampingan orang tua menjadi hal yang begitu penting bagi proses belajar. Dikuatkan oleh temuan penelitian oleh Setiawati (2015) dengan hasil penelitian bahwa adanya pengaruh pola asuh terhadap disiplin belajar siswa kelas 5 Gugus Teuku Tegal, Orang tua yang membiasakan putra-putrinya untuk terbiasa belajar dengan rutin mampu membentuk aktivitas belajar anak yang baik. Tidak hanya anak, orang dewasa pun perlu pendampingan untuk kasus tertentu sebagaimana yang disampaikan Nurkan (2016) bahwa model pendampingan terbukti berhasil dan efektif 
Rekno Handayani, Imaniar Purbasari, Deka Setiawan

TIPE POLA ASUH DALAM PENDIDIKAN KELUARGA

REFLEKSI EDUKATIKA : Jurnal Ilmiah Kependidikan, Volume 11, Nomor 1, Desember 2020, hlm. 16-23

dalam meningkatkan kemampuan pengelolaan penilaian bagi guru SD Sasaran Kurikulum 2013, hal ini bisa dibuktikan dengan analisis data yang menunjukkan ada peningkatkan, yaitu rata-rata naik 28,7 poin atau $23,9 \%$.

Dalam penjelasan salah satu informan yakni guru kelas 4, proses belajar anak akan tercapai secara maksimal dengan adanya dukungan dari keluarga. Data yang diperoleh peneliti menunjukan bahawa seorang anak yang mendapatkan pendidikan yang positif dari keluarga mampu berinteraksi serta bersosial secara baik di lingkungan tempat belajarnya serta mampu mengikuti proses belajar dan memiliki motivasi belajar yang tinggi.

Adapun pendidikan keluarga yang biasa diterapkan oleh orang tua meliputi (1) rutin beribadah, (2) keteraturan dalam belajar, (3) kemandirian di lingkungan rumah, (4) nasihatnasihat yang positif, beberapa penidikan tersebut merupakan hal yang diterapkan oleh orang tua siswa SD 1 Gulang. Tentunya hal itu tidak terlepas dari tipe pengasuhan orang tua yakni tipe pengasuhan demokratis yang mampu memberikan pendidikan keluarga yang berdampak pada kebaikan perkembangan seorang siswa. Adapun Mulyasa (2012) berpendapat bahwa nilai-nilai yang ditanamkan pada kehidupan sehari-hari dapat dicapai oleh satuan pendidikan melalui pendidikan karakter yang diterapkan. Pendidikan keluarga yang positif dapat mempengaruhi perilaku siswa untuk memiliki kepribadian yang positif pula khususnya bagi siswa SD 1 Gulang sehingga hal tersebut menjadi patokan orang tua dalam menerapkan pendidikan dalam keluarga.

Kemudian temuan selanjutnya, salah satu informan yakni Ibu TS yang memberikan pendidikan keluarga kurang maksimal terhadap anak memiliki pengaruh yang kurang baik bagi anak. Tidak terdapat pendidikan keluarga yang ditekankan oleh informan sehingga hal itu menjadi ketidak tercapaian fungsi keluarga sebagai pendidikan primer. Dalam bersosialisasi di sekolah siswa mempunyai kecendurungan tidak mampu menyesuaikan dirinya terhadap lingkungan atau pasif dan tertinggal pada proses belajar mengajar. Orang tua lebih sibuk bekerja dari pagi sampai sore sehingga tidak memiliki waktu yang banyak untuk seorang anak. Pada permasalahan ini orang tua yang kurang dalam memberikan dorongan terhadap anak akan memberikan efek yang kurang baik bagi siswa
SD 1 Gulang. Hal tersebut menjadi penekanan bahwa keluargalah yang memiliki peran utama untuk membentuk serta mengembangkan karakteristik pada diri siswa usia SD, dengan demikian tipe pola pendampigan yang menyesuaikan kondisi seornag anak atau demokratis akan memberikan output yang baik bagi seorang anak.

\section{SIMPULAN}

Hasil penelitian menunjukan bahwa siswa SD 1 Gulang yang mendapatkan pendidikan keluarga atau pendidikan primer yang baik terdapat pada tipe pola asuh demokratis. Adanya bentuk pola demokratis mampu memberikan efek atau peranan yang positif bagi anak seperti aktivitas di rumah dan di sekolah siswa mampu memiliki budi pekerti serta sikap sosial yang baik. Pada pendidikan keluarga yang menerapkan tipe demokrais mampu memberikan karakteristik positif terhadap siswa SD 1 Gulang, dengan pendidikan keluarga yang baik siswa mampu memiliki nilai religius, kemandirian, disiplin dan rajin belajar hal tersebut ditunjukan dari aktivitas siswa baik di rumah maupun sekolah.

Kemudian pada tipe pola asuh lainya yang diantaranya permisif, otoriter, dan penelantaran tidak mampu memberikan dorongan yang positif bagi siswa SD 1 Gulang. Selanjutnya Salah satu temuan orang tua yang menggunakan tipe pola asuh permisif tidak begitu memberikan motivasi dan arahan yang jelas bagi anak sehingga outputnya kurang maksimal. Oleh karenannya pendidikan dalam keluarga menjadi sangat penting bagi siswa SD 1 Gulang karena dapat berperan secara langsung terhadap masa perkembangan di usia Sekolah Dasar.

\section{DAFTAR PUSTAKA}

Anisah, Ani Siti. 2011. Pola Asuh Orang Tua Dan Implikasinya Terhadap Pembentukan Karakter Anak. Jurnal Pendidikan Universitas Garut. 5 (1): 70-84.

Euis, Sunarti. 2004. Mengasuh Anak Dengan Hati. Jakarta: PT Elex Media Komputindo.

Filisyamala, Jihan, Hariyono Hariyono, dan M Ramli. 2016. Bentuk Pola Asuh 
Rekno Handayani, Imaniar Purbasari, Deka Setiawan

TIPE POLA ASUH DALAM PENDIDIKAN KELUARGA

REFLEKSI EDUKATIKA : Jurnal Ilmiah Kependidikan, Volume 11, Nomor 1, Desember 2020, hlm. 16-23

Demokratis Dalam Kedisiplinan Siswa SD. Jurnal Pendidikan - Teori, Penelitian, Dan Pengembangan 1 (4): 668-72.

Hosokawa, Rikuya, dan Toshiki Katsura. 2019. Role of Parenting Style in Children's Behavioral Problems through the Transition from Preschool to Elementary School According to Gender in Japan. International Journal of Environmental Research and Public Health 16 (1).

Ismaya, Erik Aditia. 2012. Educational Value In Sedulur Sikep Dukuh Kaliyoso Family Desa Karangrowo Kecamatan Undaan Kabupaten Kudus. Proceeding The 4th International Graduate Student Conference on Indonesia.

Jannah, Husnatul. 2012. Perilaku Moral Pada Anak Usia Di Kecamatan Ampek. Pesona Paud 1 (1): 257-58.

Keshavarz, Somayeh, dan Rozumah, Baharudin. 2009. Parenting Style in a Collectivist Culture of Malaysia. European Journal of Social Sciences 10 (1): 66-73.

Mansur. 2005. Pendidikan Anak Usia Dini Dalam Islam. Yogyakarta: Pustaka Pelajar.

Muchlis, Masnur. 2011. Pendidkan Karakter. Jakarta: Bumi Aksara.

Mulyasa, E. 2012. Manajemen Pendidikan Karakter. Jakarta: Bumi Aksara.

Munib, Achmad. 2012. Pengantar Ilmu Pendidikan. Semarang: UPT UNNES Press.

Nurkan. 2016. Peningkatan Kemampuan Pengelolaan Penilaian Kurikulum 2013 Melalui Pendampingan Bagi Guru Sekolah Dasar. Refleksi Edukatika : Jurnal Ilmiah Kependidikan, 7 (1): 45-55.
Rohmaniyah, N. A., Khamdun., dan Widianto, E. (2020). Analisis Pola Asuh Orang Tua Pada Motivasi Belajar Siswa Kelas III SD Negeri 1 Pelemekrep. EduBasic Journal: Jurnal Pendidikan Dasar, 2 (2): 117-124.

Samsunuwiyati. 2012. Psikologi Perkembangan. Bandung: PT Remaja Rosdakarya.

Santrock, Jhon. 2002. Perkembangan Masa Hidup Edisi Ke-5 Jilid 1. Jakarta: Erlangga.

Semiawan, Conny R. 2008. Penerapan Pembelajaran Pada Anak. Jakarta: Indeks.

Setiawati, Eka. 2015. Pengaruh Pola Asuh Terhadap Kedisiplinan Belajar Siswa. Journal of Elementary Education 4 (1): 61-67.

Shocib, Moh. 2010. Pola Asuh Orang Tua Dalam Membantu Anak Mengembangkan Disiplin Diri. Jakarta: Rineka Cipta.

Suharsono, Joko Tri, Aris Fitriyani, dan Arif Setyo Upoyo. 2009. Hubungan Pola Asuh Orang Tua Terhadap Kemampuan Sosialisasi Pada Anak Prasekolah Di TK Pertiwi Purwokerto Utara. Jurnal Keperawatan Soedirman 4 (3): 112-18.

Widhiasih, Ika, Sumilah, dan Nuraeni, Abbas. 2017. Pengaruh Pola Asuh Orang Tua Terhadap Hasil Belajar IPS. Jurnal Kreatif : Jurnal Kependidikan Dasar.

Winarti. 2019. Hubungan Antara Tingkat Pendidikan Orang Tua Dengan Orientasi Pola Asuh Anak Usia Dini (Studi Di Ra Al Karimy Kec. Kutorejo Kab. Mojokerto). Proceedings The 3rd Annual International Conference on Islamic Education (AICIEd) 2019, 261-70.

Yeni, Rahmawati, et al. 2017. Strategi Pengembangan Kreativitas Pada Anak Usia Taman Kanak-Kanak. Jakarta: kencana.

Zubaedi. 2012. Desain Pendidikan Karakter. Jakarta: Kencana Media. 